\title{
PERGULATAN IDENTITAS KULTURAL ANTARA FASTFOOD DAN KUDAPAN
}

\author{
Ferdi Arifin \\ Fakultas Tarbiyah Ilmu Keguruan \\ Program Studi Pendidikan Bahasa Inggris \\ Institut Agama Islam Negeri Surakarta \\ Email: ferdiarf@gmail.com
}

\begin{abstract}
This article aims to identify a society's identity though its culinary aspect. Nowdays, fastfood has been favourite food dominating traditional one. Youth generation priorities fastfood than traditional food because they regard it more prestigious.This phenomenon can not be separated from the uses of Mass media as an important way to convey foreign product of fastfood as better culinary than local product (kudapan) selling in traditional market. This research uses qualitative methode such as library research and observation to analyze the phenomena which is happening. The finding of this research implied that cultural identity can be seen in culinary. Cultural identity in culinary is showed by its substance and making process. Thus, the implication of this research is to convey the society to love their traditional culinary as a reflex of cultural identity.
\end{abstract}

Keywords: Fastfood, Kudapan, Cultural Identity

\begin{abstract}
ABSTRAK
Kajian ini bertujuan untuk mengidentifikasi identitas suatu kelompok masyarakat melaluisudutpandangkuliner. Saatinifastfoodmerupakanmakananyangmendominasi makanan tradisional. Kebanyakan dari generasi muda lebih memprioritaskan fastfood daripada makanan tradisional karena dianggap lebih berprestise. Hal tersebut tidak lepas dari peran media massa yang mensosialisasikan fastfood sehingga memunculkan anggapan bahwa produk makanan asing lebih baik daripada fastfood lokal yang dijajakan di pasar tradisional. Penelitian ini menggunakan metode kualitatif dengan studi pustaka dan observasi untuk menganalisis fenomena yang sedang terjadi. Penelitian ini menemukan suatu identitas bangsa yang bisa dilihat dari kuliner. Identitas bangsa dari kuliner tersebut terlihat dari bahan dan proses pembuatannya. Oleh karena itu, implikasi dari penelitian ini adalah sebagai pemantik rasa kecintaan masyarakat terhadap kuliner Indonesia sebagai cerminan dari identitas bangsa.
\end{abstract}

Kata Kunci: Fastfood, Kudapan, Identitas Budaya

\section{PENDAHULUAN}

Yogyakarta merupakan salah satu kota yang berkembang pesat karena memiliki banyak tempat tujuan wisata bagi wisatawan asing maupun domestik. Hal tersebut memaksa 
perkembangan dan perubahan infraturktur kota Jogja lebih modern, meskipun hal demikian tidak diimbangi dengan perkembangan dan perubahan sumber daya manusianya. Faktor yang demikian menjadikan suatu fenomena tumpang tindih antara budaya dan manusianya.

Fenomena tumpang tindih yang demikian tidak lepas dari pengetahuan yang diperoleh masyarakat setempat terhadap pola kehidupan negara maju, dan kemudian dijadikan sebagai model kehidupan masyarakat saat ini. Hal demikian bisa dilihat dari cara pandang masyarakat saat ini yang memandang negara-negara maju, khusunya Amerika, sebagai bentuk kehidupan masyarakat yang sebenarnya. Fenomena tersebut sering kita temui ketika masyarakat memperlakukan produk Amerika seperti makanan, pakaian, atau model kehidupan lainnya (Sairin, 2001: 171).

Bentuk ketimpangan demikian juga menimbulkan kemunduran terhadap identitas budaya yang ada sebelumnya. Proses memperlakukan produk asing di dalam negeri merupakan bentuk dari suatu persepsi bahwa produk asing lebih berkualitas dan prestise daripada produk dalam negeri. Dewasa ini kita bisa melihat produk kuliner asing lebih menarik daripada produk dalam negeri, seperti hamburger, spageti, pizza, fried chicken, dan lain sebagainya.

Kuliner merupakan salah satu bentuk nyata dari mundurnya identitas budaya masyarakat sekarang. Munculnya penjual makanan cepat saji seperti Dunkin Donnut, Pizza Hut, KFC, CFC, Coca-Cola, dan sebagainya adalah bentuk kekalahan dalam persaingan kuliner. Hal tersebut terjadi karena apa yang ditawarkan oleh produk asing tersebut dianggap lebih berprestise daripada jajanan pasar.

Sebelumnya masyarakat Indonesia juga sudah mengenal kuliner gaya Eropa yang dikenal sebagai sajian ala Rijsttafel. Rijsttafel dikenal dari kata rice table adalah sajian pelengkap hidangan yang terdiri dari hidangan pembuka, hidangan utama, seperti nasi beserta lauk pauknya, dan hidangan pentup (Anonim, 2005: 2). Sajian Rijsttafel diperkenalkan oleh bangsa Belanda sebagai gambaran dari suasana makanan besar. Namun, adopsi dari Rijsttafel tersebut masih mempertahankan identitas budaya dari kuliner lokal.

Dalam penelitian ini akan menunjukkan adanya bentuk identitas budaya melalui kuliner yang sudah ada. Dengan demikian, kita akan mengetahui bagaimana produk kebudayaan itu bisa menyebar luas dan dianggap luar biasa oleh masyarakat saat ini. Disisi lain kita juga akan mengetahui bagaimana identitas budaya itu bisa muncul dalam sebuah produk kuliner, sehingga kita nanti bisa memahami bahwa saat ini masyarakat kita mengabaikan identitas budaya Indonesia, dan semoga kita bisa lebih mencintai kuliner Indonesia sebagai cerminan dari identitas bangsa ini.

\section{METODOLOGI}

Penelitian ini menggunakan metodologi observasi langsung untuk mengempulkan data. Upaya pencarian data dengan observasi langsung ini dilakukan dengan mengikuti gerak kehidupan dan perbincangan masyarakat sehari-hari. Selain itu, televise menjadi panduan untuk peneliti mengkomparasikan fenomena penggiringan opini dalam upaya pembentukan pola pemikiran bahwa kuliner asing mulai disosialisasikan.

Peneliti melibatkan diri dalam wilayah spasial dan budaya yang diteleti untuk mendengar, melihat, dan terlibat seutuh mungkin dengan para pelaku kebudayaan. Menurut Geertz (1992: 12) melibatkan diri dalam obyek penelitian akan membantu melacak lebih dalam pola kultural obyek penelitian dan menghasilakan sebuah deskripsi yang mendalam (thick description) mengenai obyek tersebut. Metode seperti ini juga sering dikenal sebagai metode etnnografi yang sama halnya seperti membaca manuskrip yang bergerak, bersifat asing, samar-samar, untuk melihat tingkah laku yang tampak pada pelaku kebudayaan. 
Dari hasil penulisan etnografi dalam fenomena di masyarakat tersebut kemudian diambah dengan studi literature untuk memperkuat analisis yang lebih dalam lagi. Penggunaan berbagai perspektif, seperti perspektif psikologi dan komunikasi, akan membantu memperdalam analisis untuk melihat eksistensi media dalam mensosialisasikan kuliner di kalangan masyarakat.

\section{EKSISTENSI MEDIA DALAM SOSIALISASI KULINER}

Media merupakan salah satu yang memiliki peran penting dalam pemasaran produk kuliner asing ke dalam negeri. Di Indonesia, media massa memiliki peran penting dalam pembentukan karakter masyarakat, seperti televisi, internet, majalah, koran, dan lain sebagainya.

Dari berbagai jenis media yang ada, televisi dan internet merupakan dua dari kesekian media yang menyuguhkan informasi populer yang dibutuhkan masyarakat, seperti gaya hidup, kuliner, wisata, dan sebagainya. Media televisi dan internet saat ini juga sudah menjadi konsumsi publik, sehingga tidak mengherankan apabila masyarakat lebih tertarik dengan kuliner asing yang ditampilkan sedemikian bagusnya daripada kuliner lokal yang selalu tampil dengan kesan kampungan dan tidak bergizi dalam media tersebut.

Televisi merupakan media setelah berjayanya zaman radio. Televisi mulai berjaya pada tahun 1950-an yang kemudian mendatangkan komunikasi visual dan mendorong timbulnya suatu teori media massa seperti analitical discourse (analisis wacana). Dalam teori itu akan menemukan gagasan-gagasan yang dieksplorasi dan suatu public sphere (pandangan publik) yang dapat dinyatakan (Briggs and Burke, 2000: 2). Oleh karena itu, informasi yang diberikan oleh televisi tidak hanya ada pada makna tersuratnya tetapi juga makna tersiratnya.

Kemudian muncul internet sekitar tahun 1965-an sebagai suatu media terbaru dan canggih karena bisa mengakses apapun yang diinginkan melalui keywords yang sudah disediakan. Peran internet di dalam masyarakat saat ini lebih cenderung ke arah anak muda karena suatu tuntutan peran dan kebutuhan belajar. Sehingga internet juga menjadi salah satu bagian dari kehidupan anak muda saat ini.

Media-media tersebut selalu menyajikan program maupun gambar yang dibuat untuk bisa dipercaya, dinikmati, dan menjadi populer. Semua yang ada pada media tersebut merupakan hasil konstruksi buatan yang dibuat senatural mungkin supaya masyarakat bisa terbawa mengikutinya (Fiske \& Hartley, 2003: 128). Program yang masuk dalam media tersebut tidak hanya sekedar acara hiburan, melainkan juga iklan-iklan yang dipasarkan di masyarakat. Isi dari keseluruhan media sendiri pada dasarnya untuk memberikan dampak terhadap masyarakat, membuat persepsi publik, memunculkan emosi dan respon, mengasosiasikan masyarakat, memunculkan ajakan, serta menciptakan tingkah laku (Wells, dkk, 2006: 97-116).

Namun, bentuk-bentuk yang ditampilkan dalam media saat ini cenderung ke arah budaya asing daripada budaya sendiri. Dari gaya hidup sampai masalah kuliner semua mengacu pada budaya asing, sehingga tidak sedikit generasi muda saat ini tidak mengetahui budaya sendiri. Oleh karena itu, kuliner asli Indonesia saat ini kalah dengan kuliner asing karena suatu bentukan dari media yang menunjukkan nilai tinggi dalam kuliner asing daripada kuliner lokal yang dibuat kesan kampungan dan tidak enak dimakan.

Masyarakat saat ini sudah banyak yang meninggalkan jajanan pasar dan lebih memilih jajanan Supermarket atau Mall-Mall mewah, juga makanan cepat saji produk luar negeri. Hal itu dikarenakan pesan yang diberikan media sukses besar bahwa jajanan pasar itu kotor dan jajanan dari Supermarket maupun Mall makanan cepat saji mereka itu enak, bergizi, dan punya nilai prestise. Oleh karena itu, eksistensi jajanan pasar saat ini sudah mulai berkurang karena akulturasi budaya yang tidak seimbang, meskipun pada dasarnya jajanan-jajanan pasar atau kudapan tersebut memiliki nilai budaya yang lebih. 


\section{FASTFOOD SEBAGAI IDENTITAS BUDAYA AMERIKA}

Fastfood mulai diperkenalkan sejak tahun 1954 oleh Swanson dalam sebuah program televisi TV Dinners, dan dari situ muncul adanya popcorn, milkshake, dan humburger (Civitello, 2008: 329-331). Saat ini kita bisa melihat fastfood atau makanan cepat saji berada dimana-mana, baik di dalam negeri maupun di negeri-negeri lain. Oleh karena itu, fastfood bisa dikatakan sebagai suatu bentuk invasi budaya dalam bidang kuliner.

Fastfood dianggap sebagai bagian dari budaya karena meliputi banyak hal seperti sosialisasi, bahan, proses pembuatan, dan fungsi fastfood itu sendiri. Seperti yang kita ketahui bahwa fastfood merupakan makanan yang identik dengan kebudayaan barat, khususnya Amerika, yang menyajikan makanan secara instan karena tuntutan konsumen yang memiliki keterbatasan waktu.

Hal tersebut muncul sebagai suatu invasi budaya karena sosialisasi fastfood terhadap masyarakat luas. Media sangat berperan penting dalam hal ini dengan menunjukkan berbagai eksistensi fastfood sebagai makanan cepat saji yang nikmat dengan membuatnya kejadian nyata (Alexander,dkk, 2006: 5). Seperti dalam sebuah film drama, seorang eksekutif muda yang sukses ditampilkan sedang memakan hamburger dan segelas coca-cola disela-sela jam istirahat kantor. Bentuk seperti itu diciptakan seakan dalam dunia nyata dan benar-benar terjadi, sehingga masyarakat yang melihat terkesan bahwa hamburger dan coca-cola adalah makanan untuk orang-orang yang ekslusif.

Masyarakat yang melihat hal itu, khususnya anak muda, akan mudah terpengaruh untuk mengikuti apa yang disampaikan oleh media. Hal demikian tidak lepas dari peran televisi sebagai hiburan utama bagi keluarga, sehingga televisi bisa dijadikan sebagai role experience saat ini. Pengalaman terhadap lingkungan merupakan sesuatu yang diadaptasi oleh masyarakatnya untuk belajar hidup (Passer \& Smith, 2008: 69). Namun, saat ini pengalaman lingkungan tersebut tergantikan oleh pengalaman yang diberikan media sebagai membentuk karakter individu. Oleh karena itu, fastfood saat ini menjadi bentuk kuliner pilihan bagi masyarakat, khususnya anak muda.

Selain dari proses sosialisasi fastfood melalui media, penggunaan bahan, proses yang dilakukan, serta fungsi fastfood sendiri mencermikan kebudayaan atau identitas bangsa penciptanya. Apabila kita melihat hamburger, KFC, maupun coca-cola, semua itu adalah cerminan dari kebudayaan Amerika pasca perang dunia kedua. Mereka menciptakan hamburger karena makanan utama mereka adalah roti, menciptakan KFC atau ayam goreng krispy karena proses pengolahan bumbu dapur mereka cenderung sedikit daripada di negara-negara tropis.

Keseluruhan dari fastfood yang mereka produksi dan mereka perdagangkan di berbagai penjuru negara merupakan identitas budaya bangsa mereka. Melalui proses media, bentuk sosialisasi kebudayaan melalui kuliner mereka kuasai sehingga negara-negara yang menjadi target pasar mengikuti kultur yang mereka buat, seperti yang ada dalam media tersebut.

\section{KUDAPAN SEBAGAI IDENTITAS BANGSA INDONESIA}

Masyarakat Indonesia saat ini sudah terjebak dalam situasi simulacrum, yaitu keadaan dalam bentuk-bentuk duplikasi yang menjadikan kita sulit untuk membedakan semua duplikasi tersebut karena tidak ada keaslian di dalamnya (Piliang, 2003: 21). Keadaan itu menciptakan masyarakat sebagai pengikut ruang simulasi tersebut terhadap apa yang diduplikasi. Bentuk duplikasi pada pembahasan ini adalah perihal budaya di dalam kuliner.

Sudah dibahas sebelumnya bahwa fastfood merupakan hasil dari kebudayaan pasca perang dunia kedua. Dijelaskan juga di atas bahwa fastfood yang mendominasi saat ini adalah milik 
negara barat, khususnya Amerika, seperti hamburger, KFC, Coca-Cola, dan lain sebagainya. Namun, pada dasarnya bangsa Indonesia, khususnya Jawa, juga memiliki makanan cepat saji seperti dalam kudapan yang lebih mencerminkan identitas bangsa Indonesia daripada hamburger maupun fried chicken.

Kudapan yang dimiliki oleh orang Jawa sangat mencerminkan kebudayaan lokal karena dari bahan-bahan yang digunakan, proses yang dilakukan, serta fungsi dari makanan itu merupakan hasil dari kebudayaan yang ada di Indonesia, khususnya Jawa. Namun, dalam kebudayaan Jawa tidak mengenal fastfood, tetapi masyarakat lebih mengenalnya sebagai sebuah jajanan atau makanan ringan, yang sering juga dianggap sebagai jajanan pasar.

Beberapajenis jajanan pasar yang sejenis dengan fastfood produk luar negeri adalah lemper, arem-arem, meniran, nagasari, carang gesing, mendut, ketan, mata kebo, apem, krasikan, putu, timus, gethuk lindri, kolak, wedang secang, wedang jahe, dan sebagainya. Beberapa jenis makanan tersebut tergolong dalam bagian kudapan, yaitu sesuatu yang berhubungan dengan makanan ringan dan dijadikan sebagai makanan pengganjal perut (Soeparno, dkk, 1998: 2947).

Apabila kita melihat macam-macam makanan tradisional tersebut, pasti akan terbayangkan dengan fastfood luar negeri. Hal itu karena fungsi dari keseluruhan makanan tradisional tersebut sama dengan fastfood milik negara asing, yaitu untuk mengganjal perut. Perbedaan yang terjadi ada pada bahan dan proses pembuatan makanan tradisional tersebut.

Kita bisa melihat identitas atau kebudayaan suatu bangsa melalui kulinernya, seperti yang ada pada makanan tradisional tersebut. Dari keseluruhan makanan tradisional di atas mengandung sekitar 100-300 kcal untuk menyumbang sekitar 15\% kebutuhan kalori perhari, dan hal tersebut tidak berbeda jauh dengan fastfood (Soeparno, dkk: 1998: 29—47). Oleh karena itu, tidak jarang kita melihat dalam acara sebuah seminar menyajikan makanan-makanan tradisional di atas sebagai makanan pengisi coffee break di antara pagi dan siang hari karena untuk mengganjal perut kosong.

Dari segi bahan-bahan yang digunakan sangat menunjukkan bahwa makanan itu semua adalah berbahan ketan, nasi, dedaunan, kanji, santan, kelapa muda, dan lain sebagainya. Semua bahan tersebut mencerminkan hasil bumi dari bangsa Indonesia, khususnya di Jawa. Oleh karena itu, bahan-bahan yang digunakan untuk pembuatan makanan pengganjal perut tersebut mencerminkan kebudayaan Indonesia.

Proses pembuatan makanan dan penyajiannya pun juga mencerminkan perilaku budaya masyarakat kita. Hal tersebut bisa dilihat bagaimana kudapan itu dibuat melalui proses yang bercirikan kebudayaan Indonesia, seperti makanan yang masih dikukus dengan alatalat tradisional, proses pengemasan yang menggunakan daun pisang maupun daun jati, dan disajikan dengan berbagai hidangan pendamping seperti jadah dengan tempe bacem, nagasari dengan teh, meniran dengan kepo, dan sebagainya.

Kudapan atau makanan pengganjal perut tadi sering dijadikan sebagai seperangkat makanan untuk upacara daur hidup. Beberapa jenis kudapan seperti ketan, kolak, dan apem adalah makanan tiga serangkai yang dijadikan simbol sebagai permintaan maaf atau nyuwun pangapura/pangapunten. Ketiga kudapan tersebut dijadikan wajib karena mengandung nilai akulturasi budaya Arab dengan Jawa. Ketan, kolak, apem merupakan perubahan nama dari khotoan, kholo'a, afwan yang diartikan sebagai 'kesalahan', 'membersihkan', dan 'minta maaf' (Anonim, 2000: 33). 


\section{KESIMPULAN}

Pada dasarnya setiap bangsa-bangsa di dunia memiliki identitas budaya melalui kulinernya. Namun, yang terjadi saat ini adalah pengaruh yang besar dari revolusi teknologi yang berkembang pesat, sehingga dominasi teknologi tersebut mereduksi identitas budaya dalam kuliner. Media massa seperti televisi, internet, majalah, dan media lainnya menjadi sarana untuk membentuk kebudayaan baru, yaitu kebudayaan populer.

Melihat dari apa yang terjadi saat ini di Indonesia, peranan media televisi sangat besar bagi masyarakat, khususnya anak muda. Media senantiasa menyajikan hal-hal yang berbau import ke dalam program-program yang disiarkannya. Hal tersebut tidak menutup kemungkinan karena pengaruh pasar yang diciptakan oleh bangsa barat sudah berhasil dalam bentuk film, iklan, berita, bahkan sampai olahraga.

Media yang turut andil dalam perubahan suatu budaya menjadi budaya populer sudah terlihat sukses. Bukti kesuksesan tersebut terlihat dari perubahan kebudayaan dalam bidang kuliner di Indonesia. Masyarakat Indonesia saat ini sudah cenderung mengikuti gaya hidup yang selalu disiarkan di televisi daripada mengikuti gaya hidup tradisional yang dianggap sudah ndeso.

Jajanan pasar sudah mulai kehilangan daya tariknya dalam masyarakat, hal ini terlihat dengan menurunnya minat masyarakat untuk mengunjungi pasar tradisionalpun. Masyarakat cenderung memilih produk import yang selalu disiarkan di televisi karena dianggap memiliki prestise yang lebih tinggi dan sesuai dengan gaya hidup saat ini. Dengan adanya fenomena ini mengakibatkan identitas bangsa mulai meredup.

Sesungguhnya apabila masyarakat sadar, makanan tradisional lebih baik untuk tubuh dan lingkungan dibandingkan dengan fastfood. Hal demikian karena makanan tradisional selalu mengutamakan bahan yang baik untuk tubuh dan lingkungan, seperti pada bungkus jajanan selalu menggunakan dedaunan. Berbeda halnya dengan fastfood produk import yang senantiasa menyajikan makanan dengan plastik ataupun stereofom yang tidak baik untuk kesehatan tubuh dan lingkungan.

Harapan dari penelitian ini adalah untuk menyadarkan masyarakat terhadap identitas suatu bangsa yang tercermin dalam kuliner. Masyarakat jangan sampai terlena dengan packaging yang ditampilkan di televisi karena itu merupakan bentuk dari kebudayaan import yang ingin dipopulerkan ke dalam kebudayaan tiap-tiap bangsa. Masyarakat harus menyadari bahwa penjajahan tidak hanya berbentuk kekerasan, melainkan juga dalam kebudayaan yang termanifestasi melalui kuliner. Oleh karena itu, marilah kita mencoba untuk mencintai jajanan pasar atau makanan tradisional karena itu merupakan bagian dari identitas bangsa Indonesia.

\section{DAFTAR PUSATAKA}

Alexander, Jeffrey C. dkk, 2006. Social Performance: Simbolic Action, Pragmatic, And Ritual. United Kingdom: Cambridge University Press.

Anonim. 2000. Makanan Tradisional Dalam Kehidupan Dan Upacara Tradisional Jawa Di Daerah Istimewa Yogyakarta. Yogyakarta: Pusat Kajian Makanan Tradisional (PMKTUGM) Universitas Gadjah Mada.

Anonim. 2005. Seri Makanan Dan Budaya. Yogyakarta: Pusat Kajian Makanan Tradisional Universitas Gadjah Mada. 
Briggs, Asa dan Peter Burke, 2000. A Social History of The Media (Terjemahan A. Rahman Zainuddin). New York: Blackwell Publishing.

Civitello, Linda. 2008. Cuisine And Culture: A History of Food And People 2nd Edition. New Jersey: John Wiley \& Sons, Inc.

Fiske, John and John Hartley, 2003. Reading Television. New York: Routledge.

Geertz, Clifford. 1992. Tafsir Kebudayaan. Yogyakarta: Penerbit Kanisius.

Passer, Michael W and Ronald E. Smith, 2008. Psychology: The Science of Mind And Behavior. New York: McGraw-Hill Companies, Inc.

Piliang, Yasraf Amir. 2003. Hipersemiotika: Tafsir Cultural Studies Atas Matinya Maknya. Yogyakarta: Jalasutra.

Sairin, Sjafri. 2001. Perubahan Masyarakat Indonesia: Perspektif Antropologi. Yogyakarta: Pustaka Pelajar.

Soeparno, dkk. 1998. Makanan Tradisional Jawa Tengah-Yogyakarta. Yogyakarta: Pusat Studi Makanan Tradisional (PMKT) Universitas Gadjah Mada.

Wells, William, Sandra Moriarty, and John Burnett, 2006. Advertising Principle And Practice 7th Edition. New Jersey: Pearson Education, Inc. 